\title{
4
}

\section{The View from London: John Barrow and Lord William Pitt Amherst}

William Pitt Amherst (1773-1857), like his embassy, has received little attention from historians who have focused either on Sir George Thomas Staunton and his role in advising Amherst against kowtowing, or on John Francis Davis's literary accounts of the British reaction to China. ${ }^{1}$ This study seeks to redress the imbalance and argues that Amherst was conscientious in discharging his duties and ably led the mission in difficult circumstances. His conduct reflected his upbringing conditioned by deeply imbued aristocratic values of allegiance to the British Crown and, by extension, the nation. A recognition of Amherst's previous experience and career as well as his personal response to his appointment is important in gauging his suitability for the position of ambassador to the Chinese Empire and for establishing his frame of mind on the eve of departure for China. The reactions of Amherst's family and friends to his appointment, found in personal letters, reveal the views held of China by the cosmopolitan and educated elite of British society at the time and are examined later in this chapter. This chapter commences with an examination of British opinions and observations in response to the proposal for a second embassy to China.

1 Tuck's (2000) analysis of the embassy, it has been noted, concentrated on Staunton (pp. vii-xlii). Kitson focused largely on Davis's writings in his Forging romantic China (2013) and 'The dark gift' (2016). 
The plan for an embassy to the Qing court in 1816 originated at Whitehall, rather than with the directors of the Company or the Select Committee at Canton. ${ }^{2}$ Regardless of Staunton's previous lobbying on the subject, the call for another embassy to China in 1815 was exclusively Barrow's initiative. His position as second secretary to the Admiralty represented one of the most important and influential civil service offices in the British Government and gave him direct access to Cabinet ministers, politicians and members of government boards. ${ }^{3}$ His reputation as the foremost British-based expert on China ensured his views carried weight at the highest levels of the government. The intelligence on which he based his argument for another embassy in 1815, however, was either outdated or had been overtaken by events. The disputes at Canton prompting the call for an embassy had been settled by the time Amherst arrived in China in June 1816. Even Staunton, it has been seen, had lost his enthusiasm for an embassy, but his more recent views were overlooked by Barrow who proceeded to promote the project with Lord Buckinghamshire, the president of the Board of Control. ${ }^{4}$

\section{Barrow Calls for an Embassy}

Napoleon's abdication in April 1814 and the restoration of Louis XVIII to the French throne ushered in a new world order with Britain as its greatest power. Both the Royal Navy and the British merchant navy reigned supreme. Britain's traditional trading rivals - the French, Spanish, Portuguese and Dutch-had been defeated and the China trade was firmly in British hands, leaving only the United States as Britain's main

2 Gao (2016, p. 598) is wrong in his assertion that 'the EIC's Court of Directors in London pleaded with the British government for [sic] sending a royal ambassador to the Qing court'.

3 Christopher Lloyd (1970, p. 75) described the Board of Admiralty. It was headed by the First Lord (Lord Melville 1812-1828) who was also a Cabinet minister. Seven members, mostly politicians, comprised the board. Two secretaries assisted the board. The first secretary dealt with the political aspects of naval affairs. The second secretary was 'responsible for running the Admiralty office and supervising the very extensive correspondence with naval officers all over the world, as well as with agents of other Boards'. Barrow was paid a salary of $£ 2,000$ in wartime and $£ 1,000$ in peacetime.

4 Lord Buckinghamshire, previously Lord Hobart, was governor of Madras from 1794 to 1798. He was reputed as being headstrong and quarrelsome (Philips, 1940, p. 183). George Canning, on the other hand, described Lord Hobart to Amherst in 1794 as possessing 'every quality in him, that can make him useful and respectable in the high situation, that he is to fill' (BL IOR MSS EUR F 140/13). Buckinghamshire had several meetings with Staunton at the time of the renewal of the Company's charter in 1812-1813; Staunton urged him to support the continuing monopoly of the China trade (Philips, 1940, p. 186). 
competitor. ${ }^{5}$ Barrow was concerned that world peace posed a potential threat to British trade with China and informed Buckinghamshire in a letter dated 14 February 1815 that these countries may be 'expected to endeavour to renew their trade in China' (Barrow to Buckinghamshire, 14 February 1815, in BL IOR G/12/196 (Reel 1) F 2-6). The French were especially threatening. Barrow believed they would get 'a start' on the British due to the mischievous French missionaries at Peking who were in 'full activity; [and who] have got the ear of the present Emperor' (Barrow to Buckinghamshire, 14 February 1815, in BL IOR G/12/196 (Reel 1) F 2-6). Buckinghamshire was warned that the British 'need not be surprised [that within the year] a communication will be made personally from the Court of France to [the Court] of Pekin' (Barrow to Buckinghamshire, 14 February 1815, in BL IOR G/12/196 (Reel 1) F 2-6). Again Barrow's judgement on this occasion was based on obsolete intelligence. The only French missionary at the Qing court was Father Lamiot who, it was noted earlier, had been in regular correspondence with Staunton. Rather, Barrow's scare campaign was based on a specific hatred of the French, understandable given a century of intermittent wars with France and his own experience at the time of the Macartney Embassy. 'The French Jesuits', Barrow wrote, were 'the enemies of Protestant England ... [and had] contributed to blast the hopes ... for the success of the British Embassy'. He continued:

That Embassy, in the general estimation of the board, failed in its object: it was indeed too soon discovered that it could not do otherwise; Demands were made, which had the Chinese character been duly appreciated, could not have been preferred. Those very demands were an admirable instrument in the hands of our Enemies who adroitly turned against us-We were ... most completely in the hands of those enemies ... Our interpreters too, were Chinese Catholics ... discovered by their countrymen [arriving in China] to be ... unworthy beings who had deserted the Tombs and the Religion of their Fathers, they had not the courage ... to advance

5 American trade increased substantially in the first decade of the nineteenth century due to the demand for tea and manufactured silk. American private traders were also exporting tea and other products from Canton into Europe. In 1815-1816, the Americans exported 4.5 million pounds of tea for American consumption and almost three million pounds of tea for European consumption, amounting to over US\$5 million. The value of Company imports and exports between Britain and China was valued at $£ 4,285,799$, with the value of exports and imports between India and China in the hands of private English traders valued at $£ 2,379,064$ (Report [relative to the trade with the East Indies and China] from the Select Committee of the House of Lords, 11 April 1821, p. 162). 
the cause of the Heretics more especially when under the eye of their Catholic Brothers. (Barrow to Buckinghamshire, 14 February 1815, in BL IOR G/12/196 (Reel 1) F 2-6)

But prospects for the success of a new British embassy were at hand. Referring to Staunton, Barrow wrote, 'We [can] now appear at the Chinese court with an advantage which we never before possessed'. He explained:

The EIC have in their employ a Gentleman who can both speak to the Chinese and write to them in their own language, without the usual recourse to the medium of any Interpreter; an advantage which can only be duly appreciated by those who have had the mortification of experiencing the intrigues and chicanery ... when communications are to be held with this jealous and corrupt government through the interventions of Catholic missionaries. (Barrow to Buckinghamshire, 14 February 1815, in BL IOR G/12/196 (Reel 1) F 2-6, emphasis in original)

Barrow, in his praise for Staunton, ignored the other English Mandarin speakers at Canton, namely, Morrison, Davis, Toone and Thomas Manning. ${ }^{6}$ News of the Jiaqing emperor's opinion of Staunton as 'the young and crafty Englishman' had yet to reach him. Staunton, in Barrow's view, was the only candidate qualified to lead an embassy to the Qing court:

It is almost needless to add that Sir George Staunton, who is now on the spot, is the gentleman to whom I allude. From a long and intimate acquaintance with him, I cannot have the smallest doubt ... that his knowledge of the [Chinese] people and their language, his zeal and integrity, joined to the solid good sense which he possesses, would at least ensure [an honourable result for the British nation]. (Barrow to Buckinghamshire, 14 February 1815, in BL IOR G/12/196 (Reel 1) F 2-6)

Opening up the Chinese domestic market for British manufacturers was also a powerful argument. Buckinghamshire was reminded of the gains to the manufacturers of Sheffield and Birmingham if 'a single Penknife

6 Thomas Manning also joined the embassy suite as a Chinese interpreter and proceeded to Peking, thus achieving his ambition of visiting the Chinese capital after earlier failed attempts to enter China through Tibet. While in Lhasa, Manning kowtowed before Tibetan mandarins and the grand lama (Markham, 1876, pp. 259, 265). A cache of Manning's papers was discovered in 2014 that have since been archived at the Royal Asiatic Society, London. A quick review of the papers in 2016 (due to time restraints) unfortunately revealed little of specific relevance to the Amherst Embassy. For a more detailed examination of Manning, see Platt (2018, pp. 140-151). 
or a pair of scissors, [produced by] the manufacturers of England, could be introduced into every family in China' (Barrow to Buckinghamshire, 14 February 1815, in BL IOR G/12/196 (Reel 1) F 2-6).

Regardless of ulterior British motives, the Chinese were to be informed that the mission was being sent in a spirit of courtly civility from the British monarch to the emperor, congratulating him specifically on his escape from the assassination attempt in 1813. The Qing court was to be notified further of the British desire for peaceful relations between the Select Committee at Canton and the provincial government.

The Company's Secret Court of Directors met in London on 3 March 1815 and agreed that an embassy could result in potential benefits provided it was 'judiciously arranged and ably executed' (Chairman and Deputy Chairman to Buckinghamshire, 3 March 1815, in BL IOR G/12/196 (Reel 1) F 7). A commission of three members was proposed. The first commissioner, or ambassador, would be nominated by the Prince Regent and would be in charge of his letter to the Jiaqing emperor. The other two commissioners were to be chosen from the Select Committee at Canton. This was to ensure that trust was not placed in a single individual. The inclusion of a gentleman nominated by the Prince Regent signified the official status of the embassy, serving to inform the Qing court of its special authority above one constituted only by men of the Company.

The choice of ambassador was an early concern. Recent British military activity in Nepal, a Chinese tributary, required a man 'best adapted to the feeling and taste of the Chinese'. 7 Such a candidate should be a 'Man of high Rank, and of Military character, and also of a pre-possessing appearance' (Chairs to Buckinghamshire, 3 March 1815, in BL IOR G/12/196 (Reel 1) F 9). Any hope Staunton may have had of returning to Peking as the leader of a British embassy was extinguished immediately by these criteria.

\footnotetext{
7 British military action in Nepal was thought to be of 'no small importance' for British interests in China. Lord Moira wrote to the Select Committee in November 1814 of a considerable Chinese force assembled in Tibet in response to Nepalese soldiers gathering on the frontier. The British had no designs on Tibet, but nonetheless, there was a 'threat of Chinese invasion of Nepaul for the purpose of imposing on that kingdom the delegations of feudal or tributary dependence, or perhaps of actually reducing it to subjection' (Letters from Lord Moira, November 1814, and Edward Gardner, British Resident, Catmandhu, in BL MSS EUR F 140/46). For a discussion on Anglo-Chinese relations concerning Tibet, Nepal and British India at this time, see Mosca (2013).
} 
Buckinghamshire and the Company's chairman and deputy chairman visited Prime Minister Lord Liverpool. His response to an embassy was, at best, lukewarm. Doubt was expressed whether he could justify the idea of another embassy to the British public after Macartney's failure. Liverpool added, however, that he would not be deterred from the pressure of public opinion if adequate reasons were put forward and would do his duty (Secret Court of Directors held Tuesday 2 May 1815, in BL IOR G/12/196 (Reel 1) F 11). The Company chairs decided to postpone any decision until news of the latest developments was received from Canton.

News from Canton dated 16 January 1815 arrived at the beginning of July. The Secret Court of Directors responded in a dispatch dated 7 July 1815. Conditions at Canton and the conduct of the 'local government of Canton to our representatives in 1814 ' had revealed:

The hazard to property and commerce of the Company [which has] been exposed by the violence, injustice and despotism of the Government - and the very precarious situation in which our affairs and the British interests operating under the unprincipled rules of those Chinese authorities-we cannot avoid seeing that it maybe our duty ... to engage the interposition and influence of H.M. government with the Court of Pekin. (Secret Commercial Letter to China, 7 July 1815, in BL IOR G/12/196 (Reel 1) F 12)

Buckinghamshire responded to this intelligence in a letter dated 26 July 1815. Details received lately from China had convinced him that the security of both Company personnel and trade at Canton 'can only be expected by the appointment of a Mission from the Prince Regent to the Emperor of China' (Chairman and Deputy Chairman of the East India Company to Buckinghamshire, 28 July 1815 and forwarded to Amherst at the time of his appointment, in BL IOR MSS EUR F 140/36). The Company chairs sent a detailed letter to Buckinghamshire's office two days later setting out the altercations that had taken place at Canton in 1813 and 1814. Focus fell on two main concerns. The Cantonese authorities, they reported, aimed to place the British Factory under their direct control. It was evident these authorities had little sense of public or personal honour and acted solely within their own interests, evidenced by their insistence that all communication with the Select Committee be in English, thus leaving scope for distorted and incorrect Mandarin translations to be passed to the Chinese Government. This strategy proved their motives of 'conceal[ing] the truth from the Emperor' and their fear of the Court of Peking (Chairman and Deputy Chairman of the East India Company 
to Buckinghamshire, 28 July 1815 and forwarded to Amherst at the time of his appointment, in BL IOR MSS EUR F 140/36). An open channel for official communication with the supreme Government of China at Peking was vital to correctly address British grievances at the highest level. Perceptions of British exceptionalism governing its affairs with the Qing court remained. Britain was 'a country whose people and whose greatness [the Chinese] are unwillingly obliged to respect', and an embassy sent in the name of the British sovereign would serve 'To place the Chinese trade on a basis of steady and fixed principles which will guard it against the fatal effects of an arbitrary, capricious, or unjust exercise of power' (Chairman and Deputy Chairman of the East India Company to Buckinghamshire, 28 July 1815 and forwarded to Amherst at the time of his appointment, in BL IOR MSS EUR F 140/36).

No new demands, concessions, or privileges were to be insisted on by the ambassador as this would serve to 'excite jealousy and resistance'; rather, his aim was to 'secure the enjoyment of privileges long conceded by the Emperor, and protection against the vexatious insults and impositions of the local authorities' (Chairman and Deputy Chairman of the East India Company to Buckinghamshire, 28 July 1815 and forwarded to Amherst at the time of his appointment, in BL IOR MSS EUR F 140/36). British intentions to observe the prescribed laws and regulations of China were to be made clear and negotiation was to centre on the following goals:

1. For the privileges of the Company to be more accurately defined and detailed.

2. To ensure trade security against sudden and capricious interruptions.

3. Freedom from the interference of Chinese Government officers in the Factory. The freedom to hire Chinese servants and an exemption from abusive, contemptuous, or insolent treatment from Chinese functionaries.

4. To open a channel of communication between members of the Factory and some public tribunal at Peking, either a British resident or by written representations in the Chinese language. And the right to use the Chinese language in all addresses and representations to the local government.

5. To give an explanation of the 'Affair of the Doris' or any other subject of a political nature on which it may be expedient to touch. 
Success in any of these was of the highest importance and the Company chairs thought it was 'worth the cost of the attempt, if that were not otherwise a matter of duty' to proceed. It was important, however, not to incur any unnecessary splendour or expense (Chairman and Deputy Chairman of the East India Company to Buckinghamshire, 28 July 1815 and forwarded to Amherst at the time of his appointment, in BL IOR MSS EUR F 140/36).

\section{Official Approval of an Embassy}

Lord Liverpool informed the Company chairs of government approval for an embassy to the Qing court on 10 August 1815. A commission made up of three commissioners was to be appointed. The second and third commissioners were named as the president of the Select Committee at Canton, John Elphinstone, and Sir George Staunton. Their contribution to the embassy would be considerable due to their local experience and knowledge of Mandarin, but it must be understood:

That the person selected by his Royal Highness the Prince Regent to be placed at the head of the Commission, and to be the bearer of the letter addressed by HRH the Prince Regent to the Emperor of China, should, as in the Government of India, be authorized to act upon his own responsibility upon any points of difference between him and the other Commissioners. (Buckinghamshire to Chairman and Deputy Chairman, EIC, 10 August 1815, in BL IOR G/12/196 (Reel 1) F 30)

Buckinghamshire's next task was finding a suitable person of rank to fill the position of ambassador on such a delicate and difficult mission. The successful candidate, as noted earlier, would be a military man as this profession, in the view of the Company Directors, was held in the highest honour by the Chinese and a man of that description 'would prove acceptable' to them as the principal member (Chairs to Buckinghamshire, 28 July 1815, in BL IOR MSS EUR F 140/36). The ambassador would receive the same allowance as Macartney, namely, $£ 20,000$ for the mission (equivalent to approximately $£ 2$ million in today's values). The Select Committee at Canton was to be notified officially that an embassy to the Qing court was being planned. ${ }^{8}$

8 Barrow had raised the matter unofficially with Staunton in his private letters, as noted earlier in this study. 


\section{Choice of a British Ambassador}

Buckinghamshire's first choice to fill the position of first commissioner or ambassador in the proposed embassy was his brother-in-law and close friend, the Rt Hon. John Sullivan, who was appointed as one of the paid assistant commissioners and had served under him when he was governor of Madras (Philips, 1940, p. 202). Sullivan had made a considerable fortune from sugar plantations in Trinidad, was a member of the Board of Control and was also a servant of the Company (Philips, 1940, p. 202). ${ }^{9}$ He was keen to take the appointment and had received Lord Liverpool's approval, but his nomination was declined by the Company Court of Directors who thought his rank and position in the Company did not qualify him for the role. Sullivan wrote to Buckinghamshire in a letter dated 26 August 1815:

Though I have a strong sense of the difficulties I should have had to encounter, with a Government so constituted as that of China ... I should not have despaired of overcoming them, if I could have carried with me a full conviction that the Court of Directors has ceased to consider it essential to the success of the Mission that it should be placed in the hands of a Peer, or of a distinguished Military character. But knowing as I now do that they continue to attach great importance to that point, I should ill deserve the good opinion of Lord Liverpool and yourself ... I decline the honour. (John Sullivan to Buckinghamshire, 26 August 1815, in BL IOR G/12/196 (Reel 1) F 36-37)

Buckinghamshire now approached Lord William Pitt Amherst and sent a letter marked 'Private and Confidential' inviting Amherst to dine with him at the Fitzroy Room to 'entertain a subject I have to mention'. He continued:

It is intended to send a Commission of Embassy to China. The business is to be conducted upon a liberal scale, but not as extravagant as in the case of Lord Macartney.

In the event of you embarking in this undertaking, I conceive you must look to an absence of two years and might expect to put twenty thousand pounds in your pocket.

9 Sullivan had resided in Madras where he 'took a keen interest in Indian affairs, personally conducting useful research at the Board into the civil and political government of India'. 
The consent of the Court of Directors is necessary. I write in Lord Liverpool's name as well as my own. (Buckinghamshire to Amherst, marked 'Private and Confidential', 29 August 1815, in BL IOR MSS EUR F 140/35)

Amherst declined the offer and Buckinghamshire approached Lord Binning. ${ }^{10}$ Binning took a couple of weeks to make up his mind. Amherst, in the meantime, had reconsidered the appointment and informed Buckinghamshire that he would accept the nomination of ambassador to China if Binning turned it down. He informed Buckinghamshire, 'I have made up my mind to a separation of two years from my family for the sake of procuring for my children a provision of $£ 20,000$ ' (Amherst to Buckinghamshire, 8 September 1815, in BL IOR MSS EUR F 140/35).

A series of secret correspondences between Amherst and Buckinghamshire followed where Buckinghamshire forwarded in 'strict confidence some extracts of my letters to Binning' (Buckinghamshire to Amherst, 9 September 1815, in BL IOR MSS EUR F 140/35). Amherst was informed on 9 September by Buckinghamshire that he was expecting Binning's answer and that 'if in the affirmative you must be aware that he must have the appointment' (Buckinghamshire to Amherst, 9 September 1815, in BL IOR MSS EUR F 140/35). Binning's answer arrived on 15 September. He had declined the appointment. Amherst was requested to meet with Buckinghamshire 'without delay' (Buckinghamshire to Amherst, 15 September 1815, in BL IOR MSS EUR F 140/35).

\section{Amherst's Appointment}

Amherst's appointment was announced to the British public on 27 September 1815. The Company's Secret Court of Directors wrote to the president of the Select Committee at Canton on the same day announcing that the Company was going ahead with an embassy to China to address the arbitrary and injurious proceedings of the local authorities towards Company representatives and interests at Canton (Draft Letter in the Secret Commercial Department to the President and Select Committee of Supra Cargoes at Canton, reference made to letters of 7 July, n.d., in

10 Thomas Hamilton, Lord Binning (1780-1858). Binning, like Amherst, was a close friend of George Canning and later served under him on the Board of Control from 1816. He was a MP for Rochester from 1818-1832. A friend described Binning as 'a thin under jawed fellow' and 'one of the pleasantest men I ever met' (see The History of Parliament, www.historyofparliamentonline.org). 
BL IOR MSS EUR F 140/43 (a)). The embassy was to consist of a person of high rank, namely, Lord Amherst, as first commissioner. The two most senior members of the Select Committee, John Elphinstone and Sir George Staunton, were nominated as the second commissioner and third commissioner, respectively, but their rank and inclusion was to be decided by Amherst on arrival in China (Staunton, 1824, p. 4).

Henry Ellis, the illegitimate son of Lord Buckinghamshire, was appointed secretary of the embassy with dormant credentials of minister plenipotentiary in the event of the death or absence of the ambassador (Castlereagh to Lord Amherst, 1 January 1816, in Morse, 1926/1966, vol. 3, p. 283). ${ }^{11}$ Ellis had returned recently from an important diplomatic mission to Persia where, acting as the deputy minister plenipotentiary at Tehran in the absence of the minister, James Morier, he had successfully engaged in negotiations with the Shah of Persia and acquired a ratification of the Anglo-Persian Definitive Treaty signed in 1814 (Sir Gore Ouseley, James Morier, Henry Ellis, in Public Records Office [PRO], Kew, UK, FO 60/9). ${ }^{12}$ His diplomatic skill was noted by Morier, who praised his efforts in achieving success during 'negotiations of considerable difficulty at Tehran' (James Morier, 21 August 1814, in PRO FO 60/9). Ellis, Morier wrote, was 'fully acquainted with the peculiar nature of the public service in Persia' (James Morier, 21 August 1814, in PRO FO 60/9). His experience of eastern diplomacy, it may be assumed, was seen as providing Amherst with valuable insight and assistance during forthcoming negotiations with the Qing court.

Lord Buckinghamshire's letter addressed to the viceroy of Canton informing him officially that an embassy was being dispatched was left unsealed so that the Select Committee could read its contents and present it together with the original and a copy of a Chinese translation. The timing of the letter's delivery at Canton was considered critical. An immediate delivery might lead the local government, acting 'from suspicion or hostility', to turn the emperor's ministers against the embassy with a danger of their

11 A secretary's task in a diplomatic mission is assisting the ambassador in drafting papers, examining documents and giving legal advice and providing the ambassador with the fruits of their professional experience (Mattingly, 1955/2010, p. 103).

12 An earlier treaty had been signed in 1812 by Ouseley. The Anglo-Persian Definitive Treaty (signed in 1814) guaranteed British military assistance in the event of European powers hostile to England entering Persian territory. Company interests in India were concerned about potential French incursions in Persia and sought to contain Russian threats that had resulted in their victory over Persia in the period 1805-1813. British embassies had pressured Persia to comply with Russian terms given that Russia was a British ally against Napoleon. 
refusing its reception. News of the embassy's impending arrival was to be kept secret and was to be announced by the presentation of the letter when the ships-of-war conveying Amherst and the embassy arrived off the coast of China. Such a strategy would leave little time for Peking to be notified and for orders to arrive at Canton forbidding the progress of the embassy (Secret Commercial Letter to China, 27 September 1815, in BL IOR G/12/196 (Reel 1) F 39-40). Short notice of the embassy's arrival, on the other hand, ran the risk of offending the Chinese as well as leaving insufficient time for the Qing court to prepare for the embassy's arrival. Accordingly, the Select Committee was instructed by the directors to use their own discretion for timing the delivery of Buckinghamshire's letter and to take the most expedient course of action 'according to the circumstances in which you find yourselves placed' (Secret Commercial Letter to China, 27 September 1815, in BL IOR G/12/196 (Reel 1) F 41).

The issues to be raised with the Chinese Government were also left to the discretion of the Select Committee. The Chinese were to be informed that Elphinstone and Staunton's inclusion in the embassy was on the orders of the Prince Regent and not the Company and the presence of several Mandarin speakers from the British Factory was necessary to relieve Staunton from translation duties. These were Robert Morrison, who had 'given so many proofs of his skill in translation from either of the two languages into the other', Robert Toone and John Francis Davis (Secret Commercial Letter to China, 27 September 1815, in BL IOR G/12/196 (Reel 1) F 41).

Amherst was scheduled to arrive in Chinese waters on 1 May 1816, at which time he was to be presented with a full report on the latest intelligence of Company affairs. The directors reminded the Select Committee that the dispatch of an embassy represented a potential hazard to British interests where trade could be stopped and it was acknowledged that this was 'a perilous expedition' (Secret Commercial Letter to China, 27 September 1815, in BL IOR G/12/196 (Reel 1) F 43). 


\section{Lord William Pitt Amherst (1773-1857)}

William Pitt Amherst, referred to as 'Pitt' by his family and close friends, was born at Bath on 14 January $1773 .{ }^{13}$ Named in honour of the statesman William Pitt the Elder, Amherst was the first of three children of Lieutenant-General William Amherst, aide-de-camp to the king, governor of Newfoundland and adjutant-general of the army, and his wife, Elizabeth Patterson. ${ }^{14}$ On the death of their parents in 1781, Amherst and his younger sister, Elizabeth, went to live with their uncle, Jeffrey Amherst, first Baron Amherst and commander in chief of the British Army, on his estate at Sevenoaks in Kent. ${ }^{15}$ Named 'Montreal' after his celebrated victory over the French during the Seven Years War in 1760, the estate offered rolling hills, horses and an ideal country life for children. Elizabeth wrote to her brother in 1800, 'Surely no two people were ever more fortunate after losing their parents, to find themselves in a better situation than if they had lived' (Hall \& Shelton, 2002, p. 49). ${ }^{16}$

Amherst was educated at Westminster School where he 'profited by the mould and conscientious rule of Dr Samuel Smith' and, at the age of 16, went to Christ Church Oxford to study for a Bachelor of Arts during the 'Saturnian reign' of Doctor Cyril Jackson from where he graduated in 1792 ('A commemoration speech on Amherst's life', read at the Christ Church Gaudy, 21 June 1876, in BL IOR MSS EUR F 140/221). Historians have concluded that young men of Amherst's aristocratic class led a sheltered existence:

13 Viscount Mersey (1949, p. 47) described the Amherst family as 'old legal gentry'. The family motto was 'Victoria Concordia Crescit' ('Victory springs from Concord') (Debrett's New Peerage for 1822, 1822).

14 Amherst's father, Lieutenant-General William Amherst, was born in 1732 and died in 1781. His mother, Elizabeth Patterson, died in 1777. The family lived on the Isle of Wight, on land inherited by Elizabeth, in a house described as a 'seven bay' Palladian style overlooking the sea (Peers, n.d.).

15 Field Marshal Jeffrey Amherst (1717-1797), 1st Baron Amherst, was instrumental in British victories against the French in Canada during the Seven Years War, including the capture of Montreal in September 1760 which ended French rule in North America. He was appointed governor-general of British North America or Canada, a position he held until 1763. Made a baron in 1776, Amherst was promoted to commander in chief of the British Army in 1778 (Peers, n.d.).

16 Amherst's youngest sister died soon after birth in 1775. Elizabeth Frances (Amherst) Hale was born at Walcott, England, in 1774 and moved to Canada in 1799 where she died at Quebec City, Quebec, in 1826. She had married John Hale and had 12 children. John Hale was the deputy paymaster British Forces in Quebec in 1798, and later became a member of Legislative Council for Lower Canada in 1808 (Hall \& Shelton, 2002, pp. 448-450). 
By their social intercourse, their classical studies, their mingling in the affairs of county society, and their travels, they could be said to have had an extensive knowledge of three things above all else, namely, ancient Rome, modern (non-industrial) England south of the Trent, and those foreign parts which customarily featured on the itinerary of the Grand Tour. (R. J. White as quoted in Plowright, 2002, p. 23)

Amherst was a quiet and inoffensive student whose 'academic performance was unexceptional' (Peers, n.d.). Nevertheless, his high birth, good looks and fine character ensured his popularity with a group of very close friends made at school and university, many of whom were destined to become the leading politicians of their generation. ${ }^{17} \mathrm{His}$ friends included George Canning, future foreign secretary (1807-1809, 1822-1827) and prime minister (1827); John Parker, 1st Earl of Morley, a prominent Whig politician and a member of the House of Lords; Lord Sidmouth, Prime Minister (1801-1804) and Home Secretary (1812-1822); Charles Abbot, Speaker of the House of Commons (1802-1817); and Charles Wynn, a future president of the Board of Control (1822-1828). Archives housed in the British Library contain several letters written to Amherst over the course of his life that provide insight into his character, career and the importance of connections and patronage in Georgian and Regency high society.

In 1794, at the age of 21, Amherst travelled to Austria at the start of a grand tour of Europe. Lady Elizabeth Holland, the English socialite, met Amherst and recorded in her journal that he was 'a quiet, sedate young man, full of proprieties and all sorts of good things' (Holland, 1909, p. 129). ${ }^{18}$ She continued, 'Mr. A. fell in love with me and Mrs. W [Mrs. Wyndham]; he was most in love with the one he last saw. We went to balls and were very gay' (Holland, 1909, p. 129). Lady Holland's group of friends reached Italy two years later where they met Lord Macartney, recently returned from the court of the Qianlong emperor and currently on a 'confidential mission to Louis XVIII at Verona' (Holland, 1909,

17 Jennifer Hall-Witt (2007, p. 17) stated the importance of 'one's dress, manners, wit, and attractiveness, as well as one's network of friends and acquaintances, which could influence one's entrance into elite social circles'. Amherst's sister referred to his good looks in the context of a newly arrived portrait of Amherst hanging 'over the chimney-piece' in 1806, adding that 'all the young ladies have fallen in love with you' (Hall \& Shelton, 2002, p. 207). Curiously, Platt (2018, p. 159) belittles Amherst as 'neither brilliant nor particularly handsome'.

18 Mrs Wyndham was the wife of the British Minister at Florence. 
p. 136). ${ }^{19}$ Lady Sarah Plymouth, married to Lord Plymouth and the mother of three children, joined Lady Holland's group in Naples. ${ }^{20}$ She and Amherst were immediately attracted to each other. Lady Holland related, 'I went with Lady Plymouth and Amherst to Tivoli; we stayed a couple of days. Lord Macartney came, and ... I saw a good deal of him' (Holland, 1909, p. 142). Lord Macartney's 'remarkable [and] retentive memory' and love of 'playing tricks' made him good company (Holland, 1909, p. 229). Whether or not Amherst and Macartney discussed China at this time is not known, but it is reasonable to suggest that the subject of Macartney's reception at the Qianlong court was raised at some point in light of his unique appointment as the first British ambassador to arrive in China and his disappointment at the failure of his mission. ${ }^{21}$ If so, such a conversation would likely have left a negative perception of China in Amherst's mind.

Amherst returned to Oxford in 1797 where he received a Master of Arts. Later that year, he succeeded to the title of Baron on the death of his uncle and was handed 'Montreal' by his aunt, the Dowager Amherst. A reference to the estate appears in an 1879 publication:

The father of the first Lord Amherst had acquired a small estate near Seven Oaks; the son extended its boundaries by the purchase of the third part of Otford and other lands. He also pulled down the old house and built himself a mansion, which he called Montreal, in commemoration of his chief victory. (Evans, 1879, p. 162) 22

Meanwhile, Amherst's and Lady Sarah Plymouth's relationship developed into a romantic affair that impacted not only on his private life but also on his career. The fact that Amherst was concerned to keep the relationship a secret from both his sister Elizabeth and the Dowager Amherst is indicated in a letter to Elizabeth written at the end of 1799, where

19 Barrow (1807, p. 356) wrote, 'in June 1795, [Macartney] was again called upon to undertake an important mission to Italy of a delicate and confidential nature, the particulars of which there are many reasons for not disclosing at present'.

20 Lady Sarah Plymouth was born Sarah Archer in 1762. She married the 5th Earl of Plymouth in 1778 when she was only 16 . She had a son and two daughters by this marriage.

21 Macartney wrote, 'I cannot help feeling the disappointment most severely' (Cranmer-Byng, 1962, p. 152).

22 The Palladian style house built by Lord Jeffrey Amherst in 1769-1770 at Sevenoaks was sold in 1926 to a local businessman where after it fell into disrepair. The house was demolished in 1936 . The original estate comprised 2,500 acres of which 60 acres were subdivided into a housing estate between 1952 and 1963 and named 'Montreal Park'. The remaining land is presently a nature reserve managed by the Kent Wildlife Trust (www.montrealpark.org.uk/history/history.htm). 
Amherst informed her that he had turned down the position of governor of Jamaica due to some 'most weighty reasons of a private nature' (BL IOR MSS EUR F 140/7). She replied in a letter dated 1 February 1800:

You say your objections to accepting the place offered you are insuperable, but do not mention them; whatever they may be I have not the least doubt of their being founded in good sense $\&$ am very glad you are not going to what I fear is a bad climate. (as quoted in Hall \& Shelton, 2002, p. 28)

His sister turned her attention to Amherst's maiden speech before the House of Lords in late 1799:

All my friends write good accounts of your Lordship's speech ... so I hope as you have begun so prosperously you will continue to exert your abilities on behalf of your Country. I am certain it only requires a little exertion for you to become a good Speaker, as you are certainly amply provided with good sense, judgment and information ... I only wish to give you a little hint to speak loud enough ... your voice naturally is not a very loud one. (as quoted in Hall \& Shelton, 2002, p. 31, emphasis in original)

Lord Plymouth, described as 'a fine Fat round English Lord', died in 1800 (Figgis \& Rowney, 2001, p. 140). His death, Lady Holland wrote, was 'a great release to his wife, who will be rewarded by marrying Amherst within the year. His constancy is unparalleled' (Holland, 1909, p. 264, emphasis in original). Amherst and Sarah were married on 24 July 1800. Their marriage was a very strong and loving union that bore three sons and a daughter. ${ }^{23}$ Amherst's sister Elizabeth was not pleased about the marriage, citing the age difference-Amherst was 27 and Sarah was 38and the fact that Sarah had three children from her previous marriage. Advantages were noted, however, and her response provides clues to the nature of Amherst's lifestyle and occupation at this time:

Your circumstances will be extremely comfortable ... Lady Amherst having so generously given up Montreal to you is a very great advantage and the farm around will be an additional employment and amusement for you. ${ }^{24}$

23 Jeffrey was born on 29 August 1802 at 'Montreal', Seven Oaks, and died on 2 August 1826 at Barrackpore, India. Jeffrey had been aide-de-camp to his father in India (BL IOL MSS EUR F 140/168). His brother, William, was born on 3 September 1805 and succeeded as the 2nd Earl on the death of Amherst in 1857.

24 Prior to his marriage, Amherst lived at 41 Duke Street, St James’s (Hall \& Shelton, 2002, p. 67). 
'Montreal' remained his family home until after Sarah's death in $1838 .{ }^{25}$ Fond references to the estate appear in several letters from friends over the years and portray an ideal country life with social gatherings spent around the fireplace in the grand house. Amherst was also fortunate in acquiring a fine London residence at 66 Grosvenor Street, Mayfair, inherited by his wife on the death of her father, whose contents were described as consisting of 'uncommonly elegant furniture' (Hall \& Shelton, 2002, p. 48).

Amherst showed little interest in domestic politics and hated public speaking (Hall \& Shelton, 2002, p. 47). His main interests were foreign affairs and coin collecting, and he was very fond of children (Hall \& Shelton, 2002, pp. 49-51). Amherst's chief occupation at this time was the management of 'Montreal' as well as activities and responsibilities connected with the very fashionable St James's Volunteers, which he joined on 31 May 1798 with the gazetted rank of colonel. ${ }^{26}$ This position entitled him to wear a splendid uniform of:

Scarlet jacket, dark blue or black facings and collar with gilt edging, gold epaulettes, gilt gorget and buttons, gilt sword-hilt, dark blue or black trousers, black helmet with plume white out of red, pink sash, silver spurs on high black boots. (Walker, 1985, Item no. 1546) ${ }^{27}$

Amherst enjoyed military service, which was hardly surprising given his family background and upbringing. He wrote to his wife from Dover in 1806 at the time of British fears of a French invasion:

I am very glad you are in town, and shall rejoice if it [an invasion] has the effect of giving me a little more military duty ... If the war continues we may be treated with a military spectacle all along the

25 Amherst's first wife, Lady Sarah, died in 1838. Amherst married Lady Mary Sackville, the daughter of the 6th Earl of Plymouth and the widow of Amherst's stepson, on 25 May 1839 at the age of 66. The couple lived at 'Knole House', Sevenoaks, one of England's grandest houses.

26 The volunteer movement was formed for the purpose of defending Britain against a French invasion. Gillian Russell (1995, pp. 13-15) has pointed out its important role in galvanising domestic support for king and country among groups that might otherwise have gravitated towards radicalism. The Volunteers were disbanded in 1802 after the Peace of Amiens, but reformed in June 1803 as the St James's Westminster Volunteers with Amherst as colonel. Amherst's sister refers to an incident in 1804 reported in a newspaper where the 'timely arrival' of Lord Amherst at the head of the Grenadier Company of the St James's Volunteers put down a 'rowdy mob' of demonstrators in Tenterden Street, off Hanover Square (Hall \& Shelton, 2002, p. 180).

27 This is a description of a portrait of Amherst in full Volunteer uniform painted in 1803 by Arthur William Devis. The portrait remained in the Amherst family until it was lent to the War Office in 1926. It was sold at Sotheby's (Amherst Sale) on 29 January 1964 and again at Christie's on 23 November 1973. 
coast, as camps succeed each other the whole way to Eastbourne without any great intervals. (Amherst to Lady Amherst, 1806, in Letters from the Yale Collection of American Literature)

\section{Amherst and the British Court}

Undoubtedly, the highlight of Amherst's early career was his appointment as a Lord of the Bedchamber to George III, a position he first held from 1802 to $1804 .^{28}$ The appointment represented a mark of royal favour and also carried an annual salary of $£ 1,000$ (equivalent to approximately $£ 100,000$ in today's values). Amherst's sister agreed that this was an opportunity that her brother could not possibly refuse, although she told him, 'it is not quite the line [of occupation] we could have wished. However, I conclude it is no bar to your taking some more active situation in future' (Elizabeth Hale to Amherst, 12 August 1802, in Hall \& Shelton, 2002 , p. 117). The opportunity to serve the king as one of his courtiers in the inner sanctum of the Court of St James's served to familiarise Amherst with the daily intricacies of court life marked by the decorous sociability of morality and taste (Brewer, 1997, p. 38). Further, the experience served to establish the subsequent context for his judgement of the manners and conduct of the Qing court, perceived as heavily ceremonial and prescribed in contrast to Regency England. The historian John Ashton wrote:

The only etiquette observed on the Terrace is, that when the King passes, the ladies and gentlemen withdraw on either side, the latter merely uncovering the head; bows and curtsies being dispensed with on the occasion [when the king stops to converse] ... this is done with the greatest urbanity. (1890, p. 8)

The fact that Amherst felt some sense of underachievement in light of the careers of his more illustrious political friends was reflected in his need to assure them that his appointment to the king's bedchamber was achieved without 'any solicitation on my part in any Quarter' (Amherst to George Canning, 28 April 1802, in BL IOR MSS EUR F 140/13). Canning replied that he never 'entertained a doubt of [Amherst] having obtained it [but] in the most honorable manner' (Canning to Amherst, 3 May 1802, in BL IOR MSS EUR F 140/13). Amherst's position was suspended momentarily

28 Amherst had three other terms as Lord of the Bedchamber: 1804-1813, 1815-1823 and 18291833 (Hall \& Shelton, 2002, p. 450). 
in early 1804 due to new arrangements in the royal household, but his quick reinstatement, brought about by Canning's recommendation, was met with an effusive response showing his high personal regard for the British monarch. Amherst wrote, 'I bow, with the utmost submission to His Majesty's demands' (Amherst to Earl of Winchilsea, 18 May 1804, in BL IOR MSS EUR F 140/11). ${ }^{29}$

While Amherst displayed a personal disdain for the behaviour of the Prince Regent, his respect, if not reverence, for the institution of the British monarchy remained steadfast. ${ }^{30}$ For men of Amherst's class and station in life, commitment to the British Crown still embodied and symbolised the highest virtues of patriotic duty and national honour at a time when British politics were increasingly becoming accountable to Parliament, the press and public opinion (Dickinson, 1999, pp. 35-42). Webster wrote in his Introduction to The letters of George IV of the importance of royal patronage for personal advancement among the closed circle of the British aristocratic elite (1938, p. lxiv). Amherst's steadfastness in upholding vigorously the sanctity of the office of the British sovereign in the face of extreme pressure from the mandarins of the Qing court during discussions with the Chinese Government is explained by such allegiance.

Amherst's owed his first diplomatic appointment in 1808 as ambassador extraordinary to the Court of the Two Sicilies to the recommendation of George Canning. ${ }^{31}$ His fluency in Italian and love of Italian culture eminently qualified him for this position, in marked contrast to his later appointment as an ambassador to China. His sister enquired of the decor at 'Montreal', 'You intended ornamenting some room with the largest general view of Rome at a distance; have you yet done so?' (Elizabeth Hale to Amherst, Quebec, 9 December 1800, in Hall \& Shelton, 2002, p. 68).

29 Canning wrote to Amherst that the Prince Regent said to him following his recommendation, 'You wish Lord Amherst restored-I shall have the greatest pleasure in restoring him' (Canning to Amherst, 6 August 1804, in BL IOR MSS EUR F 140/13).

30 Amherst referred to the 'absurd and scandalous behaviour of the Prince', which made him ashamed to visit the Prince Regent in the drawing room at Carlton House. He commented: 'and yet what can an individual do!' (Amherst to Lady Amherst, 31 May 1814, in Letters from the Yale Collection of American Literature).

31 Amherst wrote that the appointment had received the full approval of the king. He added that his interview with Canning was 'very short as he was in a hurry to prepare for the Levee, where indeed I shall have an opportunity of again seeing him. Eighteen months is the time agreed upon, but he expressed a wish that I shall not publickly [sic] name this stipulation, in order to save him the application which would already be made for the reversion. I must now dress for His Majesty' (Amherst to Lady Amherst, 14 December 1808, in Letters from the Yale Collection of American Literature). 
Amherst's two-year term at the Sicilian court, however, was described as:

Fruitless as [Amherst] tried, without sufficient support from London, to patch over the rift between Sicilian constitutionalists and nationalists and the island's nominal rulers, the exiled Bourbon king of Naples and his wife, Maria Carolina, who fought tenaciously to defend their authority. (Peers, n.d.) $)^{32}$

On his return to England in 1811, Amherst spent his time commuting between 'Montreal' and his town house in Grosvenor Street. His letters reflect a busy and carefree social life of engagements in the highest circles of aristocratic and court society. Their nature is discerned in a reference to a recital at the London residence of Lady Salisbury where a performance of 'Spanish airs' sung by a Monsieur and Madame La Font, appearing on the recommendation of the Prince Regent, was on the program. ${ }^{33}$ Amherst, whose taste in the arts was rather pedestrian, enjoyed the occasion. ${ }^{34} \mathrm{He}$ wrote to Lady Sarah, 'The harmony between [Monsieur Lamont] and his wife is quite edifying. They say they are French, but I can hardly believe it, they sing with so much taste' (Amherst to Lady Amherst, 1815, in BL MSS EUR B 363).

Amherst attended another social function a couple of nights later. His sense of humour is revealed in a letter to Lady Sarah:

I found a diamond earring ... and went about looking for an unadorned ear. I presently discovered the lady, Mrs. Harbord, and restored her trim before she was aware she was lop-sided. (Amherst to Lady Amherst, 13 June 1815, in BL MSS EUR B 363, emphasis in original $)^{35}$

32 The Bourbons ruled in Sicily under the protection of the British navy.

33 Lady Salisbury invited the singers on the recommendation of the Prince Regent who had heard them at a recital at Carlton House a few nights prior.

34 Amherst's correspondence shows little appreciation of the arts. In 1822, he attended the Hay Market Theatre with his son Jeff to see 'a laughable play called Matchmaking, and my old delight Peeping Tom [of Coventry]. I suppose I am grown grave, for Liston did not make me laugh as Edwin used to do. Amongst other songs is "Your Lordship is welcoming among us"' (Amherst to Lady Amherst, 1 August 1822, in Letters from the Yale Collection of American Literature). 'Liston' and 'Edwin' were two famous comic actors of the time. John Liston is referred to as a 'caricaturist' and Edwin played character roles depicting the lower orders of society and died in 1805 (Davis, 2015, pp. 61, 136). Robert Morrison (2019, p. 67) described Liston as relying on 'hilarious facial contortions' and making fun of conceited Cockneys and affected provincialists.

$35 \mathrm{Mr}$ Harbord was an MP. 
Amherst also described dinners held in Hanover Square with General Bligh. ${ }^{36}$ He spent a 'very merry night' with Bligh and a small group of friends at the Freemason's Tavern where a walk home after the festivities 'prevented my having a very bad headache' (Amherst to Lady Amherst, 1815 , in BL MSS EUR B 363, emphasis in original). The subject of most of his letters at this time concerned his love and affection for his wife and children. Recalling 20 years of marriage, Amherst wrote to Sarah:

What a delightful retrospect it is! And what an Angel in woman's shape art thou, my dearest. How I dwell upon all your amiable and excellent qualities, and how has possession, instead of producing satiety, only sharpened and increased my love for you. (Amherst to Lady Amherst, 12 June 1815, in BL MSS EUR B 363)

And, finally, in a letter to Sarah, who was spending time in Dublin: 'I wonder what would induce me to consent to pass another five weeks away from you ... From my breast you must never more depart' (Amherst to Lady Amherst, 7 July 1815, in BL MSS EUR B 363).

\section{Amherst's Personal Reaction to the Appointment of Ambassador}

From the earlier account of the selection process surrounding the position of ambassador to the Qing court, it is not difficult to appreciate that Binning's indecision and Buckinghamshire's concern to keep the appointment process a secret caused Amherst and his wife great anxiety. Hugh Hammersley, a prominent banker, MP and close friend of Amherst, wrote to him on 8 September $1815:^{37}$

I am anxious for an explanation of that to which you allude as a painful struggle. I conclude it is some public employ which may interrupt the fire-side happiness so dear to you. (Hammersley to Amherst, 8 September 1815, in BL IOR MSS EUR F 140/35)

36 Bligh (1769-1840) was a general in the 33rd Regiment of Foot, an MP in the Irish House of Commons (1800-1801) and a leading cricketer of the day.

37 Hugh Hammersley's father was the banker to the Prince of Wales. Hammersley (1767-1840) was MP for Helston. Known as a 'Cannonite', Hammersley, like Amherst, had been a captain in the St James's Westminster Volunteers: 'In 1826 he irritated Canning by pressing the claims of his friend Lord Amherst for an earldom' (Thorne, 1986). 
Binning's eventual rejection of the position and Amherst's decision to accept the appointment was governed principally, as noted earlier, by the inducement of earning $£ 20,000$ for his sons inheritance (Amherst to Canning, 25 September 1815, in BL IOR MSS EUR F 140/35). A further incentive, and an indication of the importance of rank in English aristocratic circles, was his expectation that the completion of a successful mission might be 'a step to the earldom' to which 'My attention has been more alive since Lady Amherst by marrying me descended from the rank of Countess to that which she at present holds' (Amherst to Canning, 25 September 1815, in BL IOR MSS EUR F 140/35).

Amherst's reduced financial circumstances at the time were well known in London high society. Charles Bagot, who was shortly appointed as the British ambassador to the United States, wrote to Binning on his decision not to accept the appointment of ambassador to the Qing court:

[You had] no choice I think but very civily to say no to it ... Amherst did right to take it. His private circumstances are very bad, without any prospect of mending it by his own exertions. (as quoted in Bagot, 1909, pp. 10-11)

Knowledge and gossip about the affairs of one's friends and acquaintances reflected in Bagot's letter are read by historians as typical of the nature of Regency high society where the exclusive circle of friends and acquaintances making up the aristocracy ensured that everyone knew all about each other's domestic situation and financial position (Webster, 1938, p. xiv). Webster wrote in his Introduction to The letters of King George IV:

Everyone knew about the incomes and the domestic circumstances of the rest-marriage difficulties, less respectful alliances, pressures of debts and the possibilities of inheritances daily canvassed in frank and familiar conversations and letters. (1938, p. xiv)

Sarah's initial reaction to Buckinghamshire's proposal was ambiguous. She informed Amherst that she had rushed to the local library, presumably at Sevenoaks, to get 'a copy of Macartney' to immerse herself in the account of his embassy (Correspondence between Amherst's appointment and departure, Sarah Amherst to Amherst, n.d., in BL IOR MSS EUR F 140/35). Remaining behind at 'Montreal' while Amherst went to London to hold discussions with Lord Buckinghamshire, she worked through her emotions while on an energetic ride with Jeffrey, their 13-year-old son. She wrote to Amherst on her return: 
My mind as you may suppose has been intent on nothing but the business of this morning - the time being only two years makes the undertaking a less one-but it is a very great sacrifice and ought to have a large temptation-If the voyage and every expense is paid by Government, so that we could be enabled to lay up our own Income it would greatly enhance the temptation. (Lady Amherst to Amherst, n.d., in BL IOR MSS EUR F 140/35, emphasis in original)

Sarah, it appeared, had hoped to accompany her husband to China, for she wrote 'if I am permitted to be with you, it matters little to me where I am' (Lady Amherst to Amherst, n.d., in BL IOR MSS EUR F 140/35). An embassy to China, in her view, was not a desirable undertaking and she expected to learn that Amherst had refused the appointment:

If not, I dare say you might merely make your own terms, for few, very few of your Rank, to say nothing of Abilities ... would consent to go and I dare say [the] Government [will] have difficulties in getting any one to accept such a Mission (Lady Amherst to Amherst, n.d., in BL IOR MSS EUR F 140/35, emphasis in original).

Sarah listed her concerns, namely, 'the climate is a matter to enquire into' (emphasis in original) as well as the length of time her husband would be away from his family. She ended her letter with a note of resignation that deferred to her husband's wisdom:

My head is not as good as yours, \& can devise nothing we have not talk'd over already ... God bless you My dearest Love - who can tell what is to happen to [us] between sun rise and sun set. (Lady Amherst to Amherst, n.d., in BL IOR MSS EUR F 140/35)

Amherst informed Canning that he was due to sail before the end of November. He added:

I am told ... I am to be joined, I believe at Canton, by the Chief of the Factory there and by Sir George Staunton (the boy in Lord Macartney's Voyage) who are to be united with me in the Commission. My absence from England will be short of two years. I conclude I may consider my appointment as decided tho' it is yet to be approved by the Regent and the Court of Directors ... I have had no judgment but my own to direct me in the decision which I have taken. (Amherst to Canning, 25 September 1815, in BL IOR MSS EUR F 140/35) 


\section{The Reaction of Amherst's Friends}

Amherst's appointment was approved formally by the Prince Regent on 2 October 1815. His family and friends were astonished at the news. The Dowager Amherst wrote that she was stunned and added:

I hope in God that the Embassy to Pekin may contribute ... much to your Happiness and Advantage as every other event in your life has hitherto done; but this is a severe trial of your good Fortune. (Dowager Amherst to Amherst, 27 September 1815, in BL IOR MSS EUR F 140/35)

Hugh Hammersley was initially quite startled when he heard the news, but thought Amherst had 'done right to make a sacrifice of two years to the future advantage' of his family, adding:

It is an undertaking of a very serious kind to be shut up for so many months on board a Ship, and in all probability to be allowed to satisfy your curiosity in a very confined degree at the end of your Sail ... The shake by the hand you gave me in the Vestry on Tuesday is not to be repeated for more than two years. I thank you much for not disclosing the Secret that day, for you would have lessened my joy and happiness most seriously. We have only to hope that if you do the E. India Company a real benefit by the Sacrifice, they will act liberally in their turn, \& the reward will be worth having. (Hugh Hammersley to Amherst, 23 September 1815, in BL IOR MSS EUR F 140/35)

Lord Boringdon agreed with Hammersley of the benefits of adding $£ 20,000$ to the family fortune but warned Amherst: ${ }^{38}$

To take care and have a most complete understanding as to the powers and situations of the two gentlemen appointed with you; so that they should not be able in case of success to reap all the credit and in the event of failure to impose the blame upon you. (Lord Boringdon to Amherst, 28 September 1815, in BL IOR MSS EUR F 140/35)

38 Lord Boringdon was Lord Morley, created in 1815 for John Parker, 2nd Baron Boringdon (Debrett's New Peerage for 1822, 1822, p. 379). 
Boringdon recommended strongly that Amherst should take his son, Jeffrey Amherst, to China. Not only was the boy of an age and character to benefit from the expedition, but also his presence would provide a source of great comfort to his father. Canning congratulated Amherst on his appointment:

I hope you continue to be well pleased with the nature of your Embassy and as hopeful of the result of it as you describe yourself at present. With every good will for your success, and your safe return, my dear Amherst. (George Canning to Amherst, 20 October 1815, in BL IOR MSS EUR F 140/13)

The prospect of a visit to China did not excite much envy among Amherst's friends. Lord Camden, who had read Macartney, wrote to Amherst, 'The country you are about to visit is rather curious than interesting but I hope you will be able to see more of it than your Predecessors have done' (Lord Camden to Amherst, 28 September 1815, in BL IOR MSS EUR F 140/35). A letter received from Doctor D. Jackson, the retired dean of Amherst's alma mater Christ Church College, Oxford, reflected a wider reading of European diplomatic overtures to China. His opinion of Amherst's coming encounter with China and its court, however, was hardly enthusiastic. He wrote:

There is a monotony in every thing belonging to China, which always tired me even when I have been reading about it ... As for the negotiations in which you are to be engaged, there is a monotony in these also. I have read I believe all the accounts of ... negotiations with the Court of Pekin that have been published, but the history of one is the history of all ... one knows I think how every negotiation was or will be begun, carried on, and [ended] — or I should rather say broken off. (Dr D. Jackson to Amherst, 2 October 1815, in BL IOR MSS EUR F 140/35)

Amherst complained later that the implementation of his embassy was marked by great haste. ${ }^{39}$ The circumstances were hardly propitious. Lord Melville, First Lord of the Admiralty, warned Amherst on 28 September 1815 that the proposed departure of the embassy on 1 December left no time to spare for making the necessary naval preparations (Lord Melville to Amherst, 28 September 1815, in BL IOR MSS EUR F 140/35). Henry Ellis, newly appointed secretary of the embassy, acted quickly

39 Amherst complained in his letter to George Canning in 1817 of his embassy being marked by 'hurry and confusion' (Amherst to Canning, 8 March 1817, in BL IOR G/12/197 (Reel 2) F 285). 
and informed Amherst four days later of his intention, to proceed to London on Sunday, that I may be in readiness to receive Your Lordship's commands, and attend to any business that may arise connected with the Embassy' (Henry Ellis to Amherst, 27 September 1815, in BL IOR MSS EUR F 140/35).

\section{Amherst's Response to the Embassy}

Amherst's appointment as the ambassador-elect to China saw him diligently research all available information on China and his choice of dinner guests at his Mayfair residence reflected the need to entertain people connected with the forthcoming embassy. Thus, on Sunday 15 October 1815, Amherst's guests were Miss Temple and her brother, Lord Palmerston, then 31 years of age and the secretary of war; $\mathrm{Mr}$ and Mrs Sullivan, presumably the Rt Hon. John Sullivan, who it has been seen was the initial choice to lead an embassy to China; John Barrow; Hugh Hammersley; and Captain Murray Maxwell of the HMS Alceste, the manof-war delegated to carry the embassy to China (Lord Amherst's 'Dinner Book' in Kent History and Library Centre, Amherst Manuscripts: Family Papers, U1350-E16). Captain Maxwell was a close friend of Amherst and is referred to in a letter he wrote to Sarah from Dover as early as 1806 (Amherst to Lady Amherst, Dover, 1806, in Letters from the Yale Collection of American Literature). Amherst also held a working dinner in late November where the absence of ladies presumably ensured an appropriate occasion for a discussion on the logistics of the embassy. Guests on this occasion were the Earl of Buckinghamshire; Chairman and Deputy Chairman of the Board of Directors of the Company, Charles Grant and Thomas Reid; Henry Ellis, Secretary of the embassy; John Barrow; Captain Maxwell and Captain Basil Hall, commander of the tengun brig HMS Lyra commissioned to accompany the Alceste to China; and Henry Hayne, Private Secretary to Amherst. ${ }^{40}$ Other guests were Hugh Hammersley and Home Secretary Henry Addington, later Lord Sidmouth (Lord Amherst's 'Dinner Book' in Kent History and Library Centre, Amherst Manuscripts: Family Papers, U1350-E16).

40 Henry Hayne had accompanied Amherst on his posting to the Two Sicilies in 1809 on the recommendation of Lord Boringdon (Hayne, n.d.). 


\section{The Composition of the Amherst Embassy}

Apart from Amherst and Ellis, other personnel assigned to the embassy included a chaplain, the Reverend Mr Griffith; two surgeons, namely, Clarke Abel who was to be paid an annual salary of $£ 500$ and Doctor Lynn who proceeded without salary. ${ }^{41}$ The embassy draftsman was William Havell, while Lieutenant Cooke was in command of the Marine Contingent. A band of 10 musicians was included who were provided with a 'packet of music' sent by the Duke of Kent, which he hoped would be 'a source of some little amusement during the voyage' (Duke of Kent to Amherst, Kensington Palace, 28 December 1815, in BL IOR MSS EUR F $140 / 36) .42$

Amherst took a personal interest in the various occupations represented in the embassy. Sir Joseph Banks called on him and requested that an intelligent Kew gardener be included to collect seeds and plants under the charge of Clarke Abel who, while attending the embassy in the capacity of a medical man, had a considerable knowledge of natural history. ${ }^{43}$ Amherst also thought a shoe maker would be a useful addition to the embassy but the Company Directors replied that this was unnecessary as it was planned to provide a sufficient supply of 'Shoes and Boots'.

On 15 October 1815, Buckinghamshire formally asked Lord Melville for a ship-of-war to be held in readiness to transport the embassy to the north of China. Amherst had written to his old friend Captain Murray Maxwell with the request that his ship HMS Alceste be commissioned to take him to China (Henderson III, 1970, p. 168) ${ }^{44}$ Maxwell responded:

Your letter has filled me with pride and happiness ... the obtaining what I so anxiously desired ... and excites such a tumult of pleasurable sensations that I am really My Lord unable to say more. (Captain Murray Maxwell to Amherst, 10 October 1815, in BL IOR MSS EUR F 140/35)

41 Clarke Abel was appointed the naturalist to the embassy at the suggestion of Sir Joseph Banks. He later accompanied Amherst in the position of physician when Amherst was governor-general of Bengal. He died at Cawnpore India on 14 November 1826. See Appendix A for a full list of the Amherst Embassy personnel sent from England.

42 The Duke stressed that he had already held a performance of the music to 'prove it was faultless' and pointed out that the score was specially calculated for the number of instruments in the band (Duke of Kent to Amherst, Kensington Palace, 28 December 1815, in BL IOR MSS EUR F 140/35).

43 See Fan (2004, pp. 18-19) for British instructions to naturalists in China to gather information and collect seeds.

44 Henderson (1970) writes that Amherst asked 'for the frigate, Alceste, commanded by his friend Capt. Murray Maxwell' (p. 168). 
Captain Maxwell was described by one historian as the ideal captain in charge of a happy ship whose crew hero-worshipped him, admired him for his seamanship and were loath to displease him (Henderson III, 1970, p. 169). The unique opportunity to sail to the north of China under the charge of Captain Maxwell attracted a request from Speaker of the House of Commons Charles Abbot for the inclusion of his 17-year-old son as a midshipman on the voyage. ${ }^{45}$ Abbot told Amherst that his son Charles had always wished to go to China:

He [has] set his heart upon it, I do not well know why, except from the desire of visiting those Seas which do not come within the ordinary chances of his Profession ... [Please] persuade the Captain to take him for one of his midshipmen ... he will [derive enviable advantages] in the company of so many persons of science. (Charles Abbot to Amherst, 11 December 1815, in BL IOR MSS EUR F 140/35)

Abbot's request was granted. He and his son paid an early call on Amherst at his Grosvenor Street residence to pay their respects before his arrival on 'the Quarter Deck of the Alceste' (Charles Abbot to Amherst, 19 December 1815, in BL IOR MSS EUR F 140/35).

China was viewed by Amherst's friends and relatives, representatives of the privileged upper class of British society, as a curious country on the far side of the world. Most of their comment was cautious, muted and dwelt heavily on the negatives: time, distance, climate and separation from family made tolerable only by the handsome financial reward attached to it. None viewed China with any enthusiasm as a destination, nor thought about its importance to Britain. Earlier reports from the Macartney Embassy portrayed China as a difficult and monotonous destination, in contrast to the exciting or exotic cultures and countries visited traditionally during the grand tour of Europe by young people of Amherst's rank. Nevertheless, Amherst approached his assignment with application and energy. How he researched China and the strategies he formed for his forthcoming coming reception at the Qing court are the subject of the next chapter.

45 Maxwell was an officer of high repute. Henderson (1970) wrote that the action of the HMS Alceste under Captain Maxwell in the wars in the Adriatic 'may have changed history' when the Alceste and two other ships intercepted a French squadron carrying 200 guns bound for Trieste on 28 November 1811. Napoleon heard the news and abandoned plans to attack Constantinople and turned instead to Moscow (p. 169). 
This text is taken from Britain's Second Embassy to China: Lord Amherst's 'Special Mission' to the Jiaqing Emperor in 1816, by Caroline Stevenson, published 2021 by ANU Press, The Australian National University,

Canberra, Australia.

doi.org/10.22459/BSEC.2020.04 